\title{
Index of Learning Styles in a U.S. School of Pharmacy
}

\author{
Colleen J. TEEVAN, Michael LI, Lauren S. SCHLESSELMAN
} Received (first version): 23-Sep-2010 Accepted: 7-May-2011

\begin{abstract}
${ }^{*}$
Objective: The goal of this study was to assess for a predominance of learning styles among pharmacy students at an accredited U.S. school of pharmacy. Methods: Following approval by the Institutional Review Board, the Index of Learning Styles@ was administered to 210 pharmacy students. The survey provides results within 4 domains: perception, input, processing, and understanding. Analyses were conducted to determine trends in student learning styles.

Results: Within the four domains, $84 \%$ of students showed a preference toward sensory perception, $66 \%$ toward visual input, and $74 \%$ toward sequential understanding. Students showed no significant preference for active or reflective processing. Preferences were of moderate strength for the sensing, visual, and sequential learning styles.

Conclusions: Students showed preferences for sensing, visual, and sequential learning styles with gender playing a role in learning style preferences. Faculty should be aware, despite some preferences, a mix of learning styles exists. To focus on the preferences found, instructors should focus teaching in a logical progression while adding visual aids. To account for other types of learning styles found, the instructors can offer other approaches and provide supplemental activities for those who would benefit from them. Further research is necessary to compare these learning styles to the teaching styles of pharmacy preceptors and faculty at schools of pharmacy.
\end{abstract}

Keywords: Education, Pharmacy, Graduate. Problem-Based Learning. United States.

\footnotetext{
Colleen J. TEEVAN. PharmD. Pharmacy Practice Resident, Saint Joseph Regional Medical Center, Mishawaka, IN (United States).

Michael LI. PharmD. Health-System Pharmacy Administration Resident, University of Washington Medicine, Seattle, WA (United States).

Lauren S. SCHLESSELMAN. PharmD. Director of the Office of Assessment and Accreditation \& Assistant Clinical Professor, University of Connecticut School of Pharmacy, Storrs, CT (United States).

(Colleen Teevan and Michael Li were PharmD Candidates at the University of Connecticut School of Pharmacy when the study was conducted).
}

\section{ÍNDICE DE ESTILOS DE APRENDIZAJE EN UNA FACULTAD DE FARMACIA DE LOS ESTADOS UNIDOS}

\section{RESUMEN}

Objetivo: El objetivo de este estudio fue evaluar la predominancia de los estilos de aprendizaje entre los estudiantes de farmacia en una facultad de farmacia acreditada en los Estados Unidos. Métodos: Después e la aprobación de la Junta de Revisión Institucional, se administró el Index of Learning Styles $\bigodot$ a 210 estudiantes de farmacia. El cuestionario proporciona resultados en 4 dominios: percepción, entradas, procesamiento, y comprensión. Se realizaron análisis para determinar las tendencias en los estilos de aprendizaje de los alumnos.

Resultados: En los 4 dominios, el $84 \%$ de los estudiantes mostró preferencias hacia la percepción sensorial, el $66 \%$ hacia las entradas visuales, y el $74 \%$ hacia la comprensión secuencial. Los estudiantes no mostraron preferencias significativas hacia el procesamiento activo o reflexivo. Las preferencias fueron de intensidad moderada hacia los estilos de aprendizaje sensorial, visual y secuencial.

\section{Conclusión: Los estudiantes mostraron} preferencias por los estilos de aprendizaje sensorial, visual y secuencial, con el género jugando un papel en las preferencias de estilo de aprendizaje. Los académicos deberían ser conscientes, a pesar de algunas preferencias, que existe una mezcla de estilos de aprendizaje. Para centrarse en las preferencias encontradas, los docentes deberían centrar la enseñanza en una progresión lógica, a medida que van aumentando las ayudas visuales. Para tener en cuenta los otros tipos de estilos de aprendizaje, los docentes pueden ofrecer otros abordajes y proporcionar actividades suplementarias para los que se puedan beneficiar de ellas. Se necesita más investigación para comparar estos estilos de aprendizaje con los estilos docentes de los tutores y profesores en las facultades de farmacia.

Palabras clave: Educación, Farmacia, Graduado. Aprendizaje Basado en Problemas. Estados Unidos.

\section{INTRODUCTION}

Learning styles are "characteristic cognitive, effective, and psychosocial behaviors that serve as relatively stable indicators of how learners perceive, interact with, and respond to the learning 
environment". ${ }^{1}$ Learners utilize a variety of learning styles and techniques. A variety of tools have been developed to assist in the identification of learning styles. When serious mismatches exist between the learning styles of students and the teaching styles of instructors, frustration develops ${ }^{2}-$ on the part of both the student and the instructor - and learning may be hindered. To reduce frustration and improve learning, the identification of student learning styles may prove beneficial. Students who are aware of their own learning preferences can use methods of studying that best suit them, particularly in situations where the instructor's teaching style does not match the student's preferred learning style. Instructors can also benefit from an increased understanding of student learning styles as a means to adapt their teaching styles to best meet the needs of the students.

Previous studies conducted on learning styles and personality types utilized a variety of tools. Shuck and Phillips examined the Myers-Briggs Type Indicator profiles, as a surrogate for learning styles, of 1,313 Drake University pharmacy students from 1987-1996. ${ }^{3}$ This study found ISTJ to be the most common personality type among the surveyed pharmacy students, accounting for $16.91 \%$ of students. During the ten year study, preferences for sensing and judging consistently predominated over preferences for intuition and perception.

Studies using the Kolb's Learning Style Inventory are the most common. Using this tool, Garvey and colleagues examined the learning styles of 501 first though fourth year pharmacy students at two schools of pharmacy. ${ }^{4}$ Half of the students were classified as convergers, while the remaining students were equally divided among accommodators, divergers, and assimilators. Students just beginning their pharmacy studies were found to be more reflective than students further along in the curriculum, and students with a previous degree were found to be more active in their learning. In 1994 Gardner and colleagues also used Kolb's tool ${ }^{5}$ to compare traditional and nontraditional students. The most common learning style for both groups was the assimilator, possibly accounting for the shift to the Doctor of Pharmacy degree and increased clinical focus since the study by Garvey and colleagues. A study conducted the University of British Columbia examined the association between student results on the Kolb's tool and preferences for problem-based learning. ${ }^{6}$ More than one-third of students were classified as accommodators. Students who were classified as divergers had the least preference for problembased learning activities, while students classified as convergers had the greatest.

Novak and colleagues at the University of Austin also evaluated problem-based learning in relation to student learning styles but used the GrashaReichmann Student Learning Style Scale. ${ }^{4}$ Students were given the scale before and after a problembased learning course. The study found scores for the collaborative learning style were high at both the beginning and end of the semester.

The objective of this study is to evaluate the learning styles of pharmacy students utilizing a different tool, the Index of Learning Styles@ instrument, in order to provide pharmacy faculty with guidance on the preferred learning styles of pharmacy students. The Index of Learning Styles(C) is an instrument developed to assess student learning preferences based on the learning style model created by Richard M. Felder and Linda K. Silverman. Developed in 1988, this model originally attempted to identify differences in learning styles among engineering students. The model classifies student learning preferences in four dimensions: perception (sensing or intuitive), input (visual or verbal), processing (active or reflective), and understanding (sequential or global). Characteristics associated with these four learning dimensions of the model are presented in Table 1.

\section{METHODS}

Following approval by the University of Connecticut Institutional Review Board, the survey was administered to students enrolled in the school of pharmacy. For first and second year professional students, the survey was administered during class, while it was administered online to third and fourth professional year students. The survey consisted of the 44-item Index of Learning Styles(C) tool and demographic data (available at: http://sn.umdnj.edu/studentsonly/cas/IndexofLearnin gStyles.pdf). Following completion of the survey, incomplete surveys were discarded, as calculation of the learning style was not possible. The Index of Learning Styles instrument was scored by investigators using the Index of Learning Styles Scoring Sheet. The scoring tool provides

\begin{tabular}{|c|c|c|}
\hline Dimension & Pole 1 & Pole 2 \\
\hline Type of Information & $\begin{array}{l}\text { Sensory (external) } \\
\text { Prefers sights, sounds, physical } \\
\text { sensations, facts, data }\end{array}$ & $\begin{array}{l}\text { Intuitive (internal) } \\
\text { Works well with possibilities, insights, } \\
\text { hunches, principles, theories }\end{array}$ \\
\hline Perception of External Information & $\begin{array}{l}\text { Visual } \\
\text { Perceives best through pictures, } \\
\text { diagrams, graphs, demonstrations }\end{array}$ & $\begin{array}{l}\text { Verbal } \\
\text { Perceives best with spoken or written } \\
\text { words, sounds }\end{array}$ \\
\hline Information processing & $\begin{array}{c}\text { Active } \\
\text { Processes through engagement in } \\
\text { physical activity or discussion, like to work } \\
\text { in groups }\end{array}$ & $\begin{array}{l}\text { Reflective } \\
\text { Works through introspection, preferring to } \\
\text { work alone }\end{array}$ \\
\hline Progression Toward Understanding & $\begin{array}{l}\text { Sequential } \\
\text { Works in continual steps }\end{array}$ & $\begin{array}{l}\text { Global } \\
\text { Make large jumps \& works holistically }\end{array}$ \\
\hline
\end{tabular}


information on the preference for one pole of each dimension and the strength of that preference. Due to the design of the tool, all scores for strength of preference are odd numbers between 1 and 11 . A score of 1-3 indicates a mild preference for that pole, a score of 5-7 indicates a moderate preference, and a score of 9-11 indicates a strong preference.

Descriptive statistics were calculated, along with statistical analysis utilizing Chi-square at a significance level of 0.05 .

\section{RESULTS}

A total of 210 students completed the survey. With a total of 404 students in the school, this provides an overall response rate of $52.0 \%$. The response rate per class varied from $11.1 \%$ of the fourth professional year class to $94.9 \%$ of the first professional year class. Demographic characteristics of students completing the survey are presented in Table 2. Although students needed to complete the Index of Learning Styles(C) tool in order for analysis to occur, some students did not provide demographic information, accounting for the discrepancy in the total number of participants and the total of number of students in some of the demographic groups.

\begin{tabular}{|lc|}
\hline \multicolumn{2}{|l|}{$\begin{array}{l}\text { Table 2: Demographic } \\
\text { Students }(N=210)\end{array}$} \\
\hline \multicolumn{1}{|c|}{ Characteristic } & No. $(\%)$ \\
\hline Age (in years) & \\
Mean \pm SD & $21.2 \pm 1.66$ \\
Gender & \\
Male & $75(35.7)$ \\
Female & $133(63.3)$ \\
Class & \\
P1 & $93(44.3)$ \\
P2 & $91(43.3)$ \\
P3 & $15(7.1)$ \\
P4 & $11(5.2)$ \\
GPA & \\
$2.0-2.9$ & $4(2)$ \\
$3.0-3.5$ & $125(62)$ \\
$3.5-4.0$ & $72(36)$ \\
\hline
\end{tabular}

Overall results showed that students had significant learning style preferences in all dimensions except the active/reflective dimension (table 3). On the sensing/intuitive dimension, students had a significant preference for the sensing learning style. Of the 210 students who completed the Index of Learning Styles@ instrument, 177 (84.3\%) preferred sensing while only $33(15.7 \%)$ preferred the intuitive learning style. Students also had a significant preference for the visual learning style on the visual/verbal dimension, with $139(66.2 \%)$ students preferring visual learning and 71 (33.8\%) students preferring verbal learning. On the sequential/global dimension, there was a significant preference for sequential learning. While only $55(26.2 \%)$ students demonstrated a preference for the global learning style, $155(73.8 \%)$ students preferred sequential learning.

The strength of preference for each learning style was also examined, based on the 1-11 scale noted earlier. The average preferences for the active, reflective, intuitive, verbal, and global learning styles were of mild strength. Moderate preferences were noted for the sensing, visual, and sequential learning styles, while no domain showed a strong preference. Figure 1 shows the average preference strength for each dimension.

\begin{tabular}{|cc|}
\hline \multicolumn{2}{|c|}{ Table 3: Overall Learning Style Results (N=210) } \\
\hline Dimension N (\%) & Number of Students \\
\hline Active versus Reflective & $103(49.0)$ \\
Active & $107(51.0)$ \\
Reflective & 0.322 \\
p-value & \\
Sensing versus Intuitive & $177(84.3)$ \\
Sensing & $33(15.7)$ \\
Intuitive & $<0.001$ \\
p-value & \\
Visual versus Verbal & $139(66.2)$ \\
Visual & $71(33.8)$ \\
Verbal & $<0.001$ \\
p-value & $155(73.8)$ \\
Sequential versus Global & $55(26.2)$ \\
Sequential & $<0.001$ \\
Global & \\
p-value & \\
\hline
\end{tabular}

Analysis was conducted to examine common combinations of domain preferences. The most common 2-domain combination, found in 142 $(66.4 \%)$ of students, was the pairing of sensing and sequential learning (table 4 ). The combination of sensing and visual learning was found in 118 $(55.1 \%)$ of students. The most common 4-domain combination, found in $46(21.5 \%)$ of students, was a preference for reflective, sensing, visual, and sequential learning. Another $43(20.1 \%)$ of students preferred the combination of active, sensing, visual, and sequential learning.

\begin{tabular}{|cc|}
\hline \multicolumn{3}{|l|}{ Table 4: Common Learning Style Combinations } \\
\hline 2-Domain Combinations & $\mathrm{N}(\%)$ \\
\hline Sensing, Sequential & $142(66.4)$ \\
Sensing, Visual & $118(55.1)$ \\
Visual, Sequential & $98(45.8)$ \\
Reflective, Sensing & $97(45.3)$ \\
Active, Sensing & $84(39.3)$ \\
Reflective, Sequential & $83(38.8)$ \\
\hline 4-Domain Combinations & $\mathrm{N}(\%)$ \\
\hline Reflective, Sensing, Visual, Sequential & $46(21.5)$ \\
Active, Sensing, Visual, Sequential & $43(20.1)$ \\
Reflective, Sensing, Verbal, Sequential & $31(14.5)$ \\
Active, Sensing, Verbal, Sequential & $27(10.3)$ \\
Reflective, Sensing, Visual, Global & $15(7.0)$ \\
Active, Sensing, Visual, Global & $14(6.5)$ \\
\hline
\end{tabular}

The final analysis was to determine if learning style differences existed in various student groups. Male and female students differed significantly in their preferences in all four domains (table 5). In the processing domain, females were more likely to prefer active learning $(p=0.03)$, while they were more likely to prefer intuitive learning in the perception domain $(p=0.001)$. As for the input domain, females were more likely to prefer verbal, rather than visual $(p=0.004)$. For the understanding domain, females were more likely to prefer global than males were $(p=0.022)$. When comparing students with GPA less than 3.5 (scale of 4.0) with those with GPA greater than 3.5, the only statistically significant difference was found in the processing domain. Students with lower GPAs were more likely to prefer reflective processing than their fellow students with higher GPAs $(p=0.001)$. No significant differences in learning style preferences were noted between professional years. 


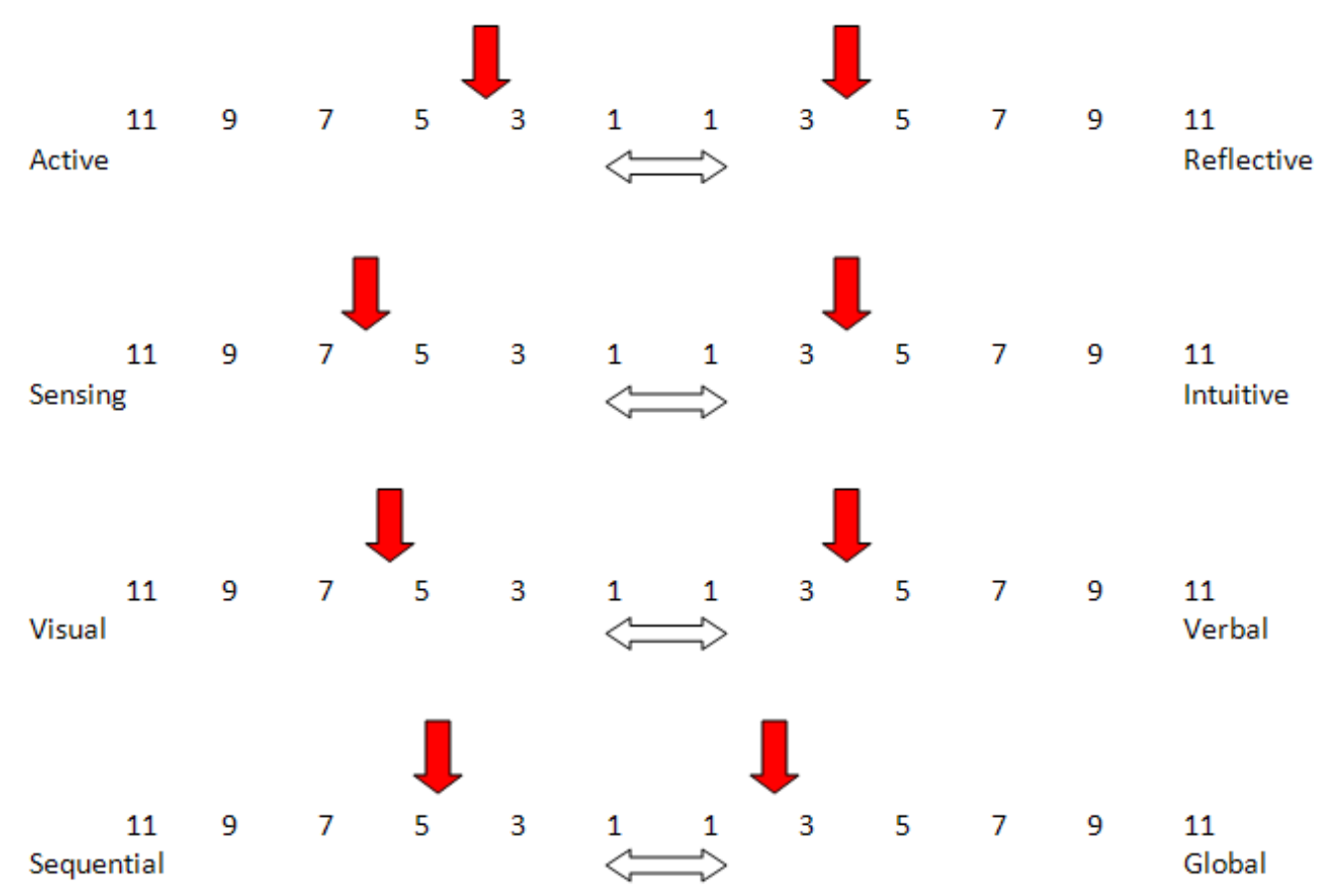

Figure 1: Strength of Learning Style Preferences

\begin{tabular}{|c|c|c|}
\hline Dimension N (\%) & Females & Males \\
\hline \multicolumn{3}{|l|}{ Active versus Reflective } \\
\hline Active & $75(56.4)$ & $30(40)$ \\
\hline Reflective & $58(43.6)$ & $45(60)$ \\
\hline$p$-value & 0.003 & \\
\hline \multicolumn{3}{|l|}{ Sensing versus Intuitive } \\
\hline Sensing & $15(11.3)$ & $19(25.3)$ \\
\hline Intuitive & $118(88.7)$ & $39(74.7)$ \\
\hline p-value & 0.001 & \\
\hline \multicolumn{3}{|l|}{ Visual versus Verbal } \\
\hline Visual & $56(42.1)$ & $16(21.3)$ \\
\hline Verbal & 77 (57.9) & 59 (78.7) \\
\hline $\mathrm{p}$-value & 0.004 & \\
\hline \multicolumn{3}{|l|}{ Sequential versus Global } \\
\hline Sequential & $28(21.1)$ & $27(36)$ \\
\hline Global & 105 (78.9) & 48 (64) \\
\hline$p$-value & 0.022 & \\
\hline
\end{tabular}

\section{DISCUSSION}

The Index of Learning Styles( was chosen as the learning style instrument for several reasons. First, the instrument was developed specifically for use in the classroom. The instrument has been administered to hundreds of college students with studies showing it to be valid and reliable. ${ }^{3}$ In addition, this instrument examines student preferences in four different dimensions whereas many other instruments examine only two dimensions. The instrument is also simple to administer, requiring only 10 minutes to complete. Although the Pharmacists' Inventory of Learning Styles was developed specifically for the profession of pharmacy, it was not used in this study because it is relatively new, is not widely used, examines only two learning dimensions, and was validated in a small number of individuals.
Since previous studies of learning and personality styles of pharmacy students have used different instruments, comparisons with previous results are difficult to make. The sensing/intuitive dimension of the Index of Learning Styles(C) corresponds to the sensing/intuition dimension of the Myers-Briggs instrument and the concrete experience/abstract conceptualization aspects of Kolb's Learning Styles Inventory. The identification of a preference for the sensing learning style is consistent with the findings of the study by Shuck and Phillips, which found ISTJ to be the most common personality type among pharmacy students. ${ }^{3}$ Of the previous studies that used Kolb's tool, the results of this study are most consistent with Pungente's study, which found more students to be accommodators than any other type. ${ }^{6}$ One of the preferences of an accommodator is concrete experience, which correlates with the sensing preference in the Index of Learning Styles(C). The studies by Garvey and Gardner found a preference for abstract conceptualization, which corresponds to the intuitive learning style in the Index of Learning Styles@.

All of the learning styles identified by the Index of Learning Styles@ are present among pharmacy students at the University of Connecticut, but significant preferences were noted for sensing, sequential, and visual learning. Preceptors and faculty at the University of Connecticut can use this information about student learning styles to ensure they are meeting student learning needs. This is not to say that preceptors and faculty should adjust their teaching methods to focus on sensing, visual, and sequential learners to the exclusion of students with less common learning styles. Rather, preceptors and faculty should realize that pharmacy students 
learn in a variety of ways and attempt to incorporate all learning styles in their teaching. To address both active and reflective learners, the combination of lectures with pauses for thought and reflection and discussion or problem-solving activities may be highly effective. In addition, offering opportunities for both group and individual work will appeal to active and reflective learners, respectively. In order to teach both sensing and intuitive learners, preceptors and faculty who are instructing pharmacy students should aim to blend facts and concepts. Facts and data will appeal to the sensing learner, while theories and principles appeal to the intuitive learner. Addressing both a fundamental understanding and practical, problem-solving application of material will ensure that the needs of both types of learners are met.

Verbal and visual learners will also benefit from some of the previously mentioned learning strategies. A traditional lecture, combining an oral presentation with slides or other written materials, addresses verbal learning while discussion about the material would further aid a verbal learner. The inclusion of pictures, diagrams, graphs, and flow charts into lectures, along with videos and demonstrations, when appropriate, would promote understanding among visual learners.

Most courses address sequential learners, with syllabi, course materials, and textbooks being set up in a logical progression of increasing difficulty or complexity. In order to aid global learners in their understanding, instructors should aim to provide an overview of the big picture and relevance of the material being discussed. Relating the material to other courses and previous experiences will benefit the global learners. In particular, preceptors can relate discussions and presentations to patient cases seen by the students.

When interpreting and using learning styles results, we should keep several important factors in mind. First, each learning style dimension being assessed is a continuum, not an absolute. A student's identified learning style represents trends in his or her behavior and a preference for that method of learning. This is not to say, however, a student will always behave in one set way. The strength of a student's learning style preferences, as well as the specific situation, will influence the student's learning behaviors. ${ }^{7}$

Second, a student's learning style preferences may change over time. Preferences may change due to exposure to certain teaching styles intended to promote a different type of learning. One study of pharmacy students demonstrated that student learning style preferences changed during the course of a semester simply as a result of a problem-based learning course. ${ }^{8}$

Finally, as it would be rare for all of the students in an experiential or didactic course to have identical learning styles, preceptors and instructors should aim to include all learning styles in their teaching. Students often learn better when their learning style and the instructor's teaching style match. Yet it is important that students develop the skills of multiple learning styles, as proficiency in all styles may prove necessary. ${ }^{3}$

On the other hand, preceptors and faculty should recognize the presence of various learning styles, along with the predominance of some styles, when teaching. Providing information in formats that will meet the needs of students may increase learning.

A limitation of this study is the poor response rate of students in their third and fourth professional years. Because the survey was administered online for these students, rather than before a class, they were less likely than students in their first and second professional years to complete the survey. This may have impacted the ability for the study to find differences between learning styles of each professional year.

Another limitation is that the surveys were anonymous and scored by the researchers, rather than the students. As a result, students were not made aware of their individual learning style. This limited the students' ability to determine whether their learning style result was an accurate representation of how they learn best. Additionally, students were unable to apply knowledge of their learning style to improve their studying and learning techniques. Not having the surveys matched to individual students also limits the researchers' ability to track changes in individual students throughout their time as a pharmacy student. Furthermore, the anonymous nature of the study prevented the opportunity to correlate student learning styles with academic performance in courses utilizing different teaching styles. The GPAs utilized in the study were self-reported by the students and could not be verified with academic records. Matching students with academic records may have also been beneficial.

Many opportunities exist for future studies in the area of learning styles among pharmacy students. Larger scale studies should be conducted to assess student learning styles at multiple schools of pharmacy. Additionally, it may prove useful to follow students as they progress through the curriculum, allowing for an evaluation of whether any changes in the students' preferred learning style occur throughout the course of their pharmacy education. There may also be use in examining whether a correlation exists between a student's learning style and their success in the pharmacy program, as evidenced by grades in individual courses. Finally, an examination of the teaching styles of pharmacy preceptors and faculty should be conducted to determine the compatibility of student learning styles with faculty teaching styles.

\section{CONCLUSIONS}

Students showed preferences for sensing, visual, and sequential learning styles but no preference for active or reflective learning. Male and female students showed different learning style preferences. Preceptors and faculty should be aware, despite some preferences, a mix of learning styles exists in the classroom. To focus on the preferences found, instructors should focus 
teaching in a logical progression that includes facts and data while adding visual aids. To account for other types of learning styles found, the instructors can offer other approaches and provide supplemental activities for those who would benefit from them.

Future studies should focus on examining a correlation between learning style and academic success in pharmacy school as well as potential changes in pharmacy students' learning styles over time.

\section{CONFLICT OF INTEREST}

Authors have no conflicts of interest to declare.

\section{References}

1. Romanelli F, Bird E, Ryan M. Learning Styles: A Review of Theory, Application, and Best Practices. Am J Pharm Educ. 2009;73(1):9.

2. Felder RM, Silverman LK. Learning and Teaching Styles in Engineering Education. Engr Education. 1988;78(7):674681.

3. Shuck AA, Phillips CR. Assessing Pharmacy Students' Learning Styles and Personality Types: A Ten-Year Analysis. Am J Pharm Educ. 1999;63:27-33.

4. Garvey M, Bootman JL, McGhan WF, Meredith K. An Assessment of Learning Styles Among Pharmacy Students. Am J Pharm Educ. 1984;48:134-140.

5. Gardner SF, Monaghan MS. Comparison of Learning Styles Between Traditional and Nontraditional Pharmacy Students in a Doctor of Pharmacy Program. J Pharm Teach. 1996;5(4):31-39.

6. Pungente MD, Wasan DM, Moffett C. Using Learning Styles to Evaluate First-Year Pharmacy Students' Preferences Toward Different Activities Associated with the Problem-Based Learning Approach. Am J Pharm Educ. 2003;66:119124.

7. Felder RM, Spurlin J. Applications, Reliability and Validity of the Index of Learning Styles. Int J Engng Ed. 2005;21(1):103-112.

8. Novak S, Shah S, Wilson JP, Lawson KA, Salzman RD. Pharmacy Students' Learning Styles Before and After a Problem-based Learning Experience. Am J Pharm Educ. 2006;70(4):74. 